\title{
The Role Of English Students Association (Esa) For Developing The English Skills Of English Education Department Students At Stain Kudus
}

\author{
Suciati ${ }^{1 *}$, Nurul Aini Rizqina ${ }^{2}$, Nadhifan Dzulfahmi ${ }^{3}$ \\ 1,2,3 English Education Department, Institut Agama Islam Negeri Kudus, Kudus, Indonesia
}

\begin{tabular}{|l|l|l|l|}
\hline Contact: & Suciati & $\boldsymbol{B}$ & suciati@iainkudus.ac.id \\
\hline
\end{tabular}

\begin{abstract}
This study aims to identify the role of English Students Association (ESA) in developing English Skills of English Education Department (EED) students, identify the factors influencing the students to develop their English Skills in ESA and find the solution for the problems. This descriptive qualitative study was conducted at STAIN Kudus, especially on ESA programs or activities. The participants of this research were the students of English Education Department STAIN Kudus who join ESA. The data were collected through observation, interview, and documentation analysis. There were three results. First, the role of ESA in developing English skills of English Education Department students is important and very big, especially for improving their speaking skills (listening, speaking, reading, and writing). Second, there are internal and external factors influencing the English Education Department students to develop their English Skills in ESA. The internal factors are students' self-motivation and character. And the external factors are environment (class or other friends' condition/influence), syllabus/lesson plan, materials/programs, teaching technique/strategy, level of regulation, and several agenda/programs in the same time. Third, solutions for the problems are the existence of clear organization structure and regulation, well-organized materials/class, interesting and fun programs, students and lecturers' support and appreciation.
\end{abstract}

\section{KEYWORDS:}

English Students Association

(ESA);

English Skills;

English Education

Department;

\section{Introduction}

English learning and teaching has a purpose for students to be able to communicate using the English language well. In practice, all language skills are very important and must be in synergy. These skills are listening, speaking, reading, and writing. Usually, learners find many difficulties in communicating, 
especially if English is as Foreign Language (EFL) for them. The difficulty in using English correctly leads to a lack of confidence.

In teaching and learning English, speaking is the most important skill because it is the basis for communication. Shumin in Oradee $(2012$, p. 533) states that communicating using English is so hard for most learners. In particular, EFL learners often stammer when they speak English. This happens because they are not accustomed to communicate and express every idea using English. According to many teaching scientists, communicative activities can develop speaking skills. Hedge (2008) also stated that it should be supported by ideas or activities that can help them to learn and practice better. Thus, it can be understood that support and opportunities to learn independently and freely are expected by all learners.

Such condition also occurs in the environment of Kudus State Islamic College (STAIN) Kudus, especially students of English Education Department. On this campus, the English Education Department is included in the category of a newest study program as its lecture is just started legally this academic year 2017/2018. For that reason, being the first students in this department is not easy because of many challenges and problems encountered. One of them is the lack of space to practice using English. Many English Education Department students stated that their occasion to develop is still very limited. They can only practice English maximally and freely when they are in English class because all of them are one community there. If they use English outside the classroom, there are still many students from other departments or study programs who have not been able to accept their full existence when they communicate in full English. Therefore, an occasion (place and time) for students of the English Education Department is indispensable.

So far, there is a Students Activity Unit/Organization or Unit Kegiatan Mahasiswa (UKM) for studying English at STAIN Kudus, namely STAIN English Club (STEC). However, this club is for all STAIN students in general. They are for all students from any study program. Of course, students of English Education 
Department cannot develop their English proficiency maximally because the number of STEC members is so high. It can be analyzed and known from the quantity of study programs for graduate degree which are available in STAIN. There are 26 study programs there. They are 10 study programs in Tarbiyah Department, 7 study programs in Sharia and Islamic Economics, 4 study programs in Ushuluddin Department, and 5 study programs in Department of Da'wah (http://stainkudus.ac.id/).

In addition, the educational backgrounds of the English Education Department students are so various. They are graduates or alumni from Senior High School (SMA), Islamic Senior High School (MA), or Vocational High School (SMK). Thus, it can be seen that their English skills are also very different. There are students who have the ability to communicate using English well, average, or even some are in the category of minimal. From these different abilities, finally they have different self-esteem. On campuses that have English Education Department, they usually have a special association for English Education Department students. It is English Students Association (ESA). This is a creative, academic, active and dynamic student's organization in English Education Department. This organization aims to accommodate aspiration and facilitate the students of English Education Department in developing the students' English proficiency and creativity.

The availability of space or association that accommodate the students for English Education Department specially is needed. Hopefully, they can develop or enhance their English skills well. As English lecturer, the researcher has responsibility to facilitate them to study well. She has big intention to make an English organisation or association that is special for English Education Department students. It has got positive response from the head of Tarbiyah department, STAIN Kudus. Hopefully it will be received and responded well by the others so English Education Department students can develop their ability outside the class maximally. For those above reasons, the researcher conducted 
a study entitled "English Students Association (ESA) for Developing the English Skills of English Education Department Students at STAIN Kudus"

This article explores the role of English Students Association (ESA) in developing English Skills of English Education Department students at STAIN Kudus, identifies the factors influencing the English Education Department students at STAIN Kudus to develop their English Skills in English Students Association (ESA) and finds the solution for the problems of English Education Department students at STAIN Kudus in developing their English Skills in English Students Association (ESA).

There are some previous studies that have been conducted with focus on developing English language skills. They are as follows. Students' Language Skills Development through Short Stories by Rodriguez (2017). The purpose of this article is to share with English teachers; that is to describe the impact of developing the students' language skills through listening and reading short stories. The research was conducted among students of the third semester at Universidad Santo Tomas - Tunja (USTA), Colombia. The type of research is collaborative action research. Therefore, the instruments used to collect information are student documents (written essay and oral report), teacher journal, and a survey. The results of the study are: students get a significant advantage in vocabulary and expression through reading and listening; reading is useful in improving their speaking; and students' readiness to target languages encourages them to improve language acquisition and practice. This research also encourages students' awareness of literature.

Using Communicative Games in Improving Students' Speaking Skills by Dewi, R.S, Kultsum, U. dan Armadi (2017). The purpose of this study was to find out whether communicative games have an impact on teaching speaking skills and illustrate how communicative games affect the students' speaking skills in Junior High Schools in Jakarta, Indonesia. Classroom Action Research (CAR) is implemented based on Kurt Model L. The procedures used are planning, acting, observing, and reflecting. It is done into two cycles. Each cycle consists 
of three meetings. Researchers used collaborative action research with several English teachers. In collecting data, the instruments used are interviews, observation, questionnaires and tests. The test is only given to students.

The results of this study showed the average score reached 60.42 to 69.02 and post test score reached 78.77 . This means there is a significant increase of $13.9 \%$ to $41.7 \%$ in post test 1 and $83.33 \%$ in post test 2 . It is also known that communicative games have a positive impact on the learning process. This shows that communicative games are expected to increase students' enthusiasm and motivation. A positive improvement in students who actively participate is an increase in their confidence and fluency in speech.

Role of ICT in the Enhancement of English Language Skills among the Learners by Akhtar (2016). The usage of modern approaches and tools of ICT (Information and Communication Technology) is necessary. It can be used to develop a better understanding and acquisition of basic skills of English (Listening, Speaking, Reading and Writing) among school-level students. This study shows the positive results of ICT integration in the field of ELT and the development of English language proficiency. This facility has paved the way for students to learn independently and provide freedom to learn anytime, anywhere in accordance with the students' needs and comfort. From the review of previous studies above, it is so clear that they have differences with the study which was conducted by the researcher.

\section{Method}

In this study, the researcher used descriptive qualitative study. Lamber, V.A and Lamber (2012: 255) explain that descriptive qualitative study has little "theoretical" if it is compared with other qualitative approaches. It tends to describe the naturalistic inquiry and takes the commitment to study something in its natural state fully so that it is possible within the context of the research arena. The participants of this research are all students of English Education Department STAIN Kudus who join ESA. Their number is 71 students (36 
students from class A and 35 students from class B). Based on research methodology that is used in this research, the data collecting techniques were in the form of observation, interview and document analysis.

One of the techniques of collecting data is observation. This technique is used to get data from the source of data as event, place, and things or documents (Sutopo, 2006, p. 64). According to Spradley in Sutopo (2006), the implementation of observation can be divided into non-participant observation and participant observation. This research used participant observation, so the researcher join in all events and activities done by observed subjects. The observation focuses on the teaching and learning process or activities held by English Students' Association (ESA) STAIN Kudus. Through the observation, the researcher portrayed the value of the phenomenon.

Interview is a dialog done by the interviewer to get some information from the interviewee (Arikunto, 1998). And, the interviewee or informants are the members of ESA, the tutors/facilitators, and other related parties. In this study, the researcher will use in-depth interviewing research type to investigate deeply about the interviewee's experience in ESA STAIN Kudus. Bungin (2003) states that by using in-depth interviewing, something in the heart related to the past, at present, even in the future can be searched deeply. On the other way, their experience can be symbolized through their languages. In-depth interviewing can be used to analyze the people experience and its meaning. The technique is performed to collect data whether they are in the form of documents or archives. Lincoln, YS. and Guba (1985) define documents as all written materials or film that is not prepared because of the investigating asks (researcher). The analyses of documents will be focused on the chosen documents. They include data of students, schedule of program, and openended questions. The aim is to contribute the data observation and data interview. 


\section{Result}

In English language, there are four skills (Harmer, 2007). The first is listening. The skill that someone must master before speaking is listening. This is very important to master first before he speaks. The second skill is speaking. It is one skill that must be mastered so a speaker can communicate or convey his intent and purpose. The next one is reading. By this skill, someone will get more information and knowledge. And, the last skill is writing. Writing is an English skill which is difficult enough because someone must know the structure or grammar.

According to Verghese in Raja, B.W.D and Selvi (2011), there are so many factors affecting the process of learning a second language. They are attitude, self-confidence, and motivation, duration of exposure to the language, classroom conditions, environment, family background, and availability of competent teachers. Meanwhile, Khajloo (2013, pp. 56-57) mentions five problems in English teaching and learning. They are lack of interest and motivation, lack of concentration, students who join English course, the lack of the English teacher's proficiency and lack of repetition and frequent practice of students. For the lack of concentration, it is influenced by some factors. They are fatigue and insomnia, environment and family problems.

According to Leask, B. and Carroll (2013), there are six principles for developing students' English language skills. They are (1) Focusing on students as learners; (2) Respecting and adjusting for diversity principle; (3) Providing context-specific information and support; (4) Having good teaching across cultures will enable meaningful intercultural dialogue and engagement; (5) Being adaptable, flexible and responsive to evidence; and (6) Preparing students in having better life in globalization era.

ESA which stands for "English Students Association" is one student association on the department level which is composed of the English Education Department students. This organization can be found everywhere, especially campus which has English Department. ESA has the beneficial 
activities both academic and non-academic which aims to encompass the creativity, interest and talent and also aspiration coming from either the English students or lecturers.

This organization is usually used to facilitate English department students to develop more, not just doing activities in classroom. It is under the English Education Department or Study Program. This association has meeting or program every Thursday to study English together. The organization structure of ESA is like below.

The role of English Students Association (ESA) in developing English skills of English Education Department students at STAIN Kudus is important and very big, especially for improving their speaking skills. The students study some materials there. For example, tongue twister, role play, speech, MC and debate. The materials are given by the tutors from the lecturers or the peers/students.

In implementing the ESA programs, there are two factors influencing the English Education Department students at STAIN Kudus to develop their English Skills in English Students Association (ESA). They are internal and external factors. The internal factors are students' self-motivation and character. And the external factors are environment (class or other friends' condition/influence), syllabus/lesson plan, materials/programs, teaching technique/strategy, level of regulation, and several agenda/programs in the same time. Third, solutions for the problems of the English Education Department students at STAIN Kudus in developing their English Skills in English Students Association (ESA) are the existence of clear organization structure and regulation, well-organized materials/class, interesting and fun programs, students and lecturers' support and appreciation.

\section{Discussion}

Based on the result of the study, there are three points discussed in detail. They are role and factors influencing the English Education Department 
students at STAIN Kudus to develop their English Skills in English Students Association (ESA), and solutions for the problems.

Role of English Students Association (ESA) in developing English Skills of English Education Department students at STAIN Kudus. After doing observation, open ended questions and interview, the condition of ESA can be known in detail. All students do realize that the existence English Students Association (ESA) in developing English skills of English Education Department students at STAIN Kudus is very big. They can study all skills from it. They are listening, speaking, reading, and writing. Nevertheless, the skill that they can improve better from that program is speaking.

The students of ESA are students of English Education Department, IAIN Kudus. Their number is 71 ( 36 from class $A$ and 35 from class $B$ ). They are the first year students in that department/study program because it is legally started in the academic year of 2017/2018. It means that they do not have seniors or upper semester friends from same study program. Moreover, they have various background. They were from Senior High School or Sekolah Menengah Atas (SMA), Islamic Senior High School or Madrasah Aliyah (MA) and Vocational High School or Sekolah Menengah Kejuruan (SMK). For that reason, they also have different ability and skills. The basic English language skill that they want to master first as the foundation is speaking. Some of them are so fluent to speak English. But some of them still find the difficulties to speak. For them, speaking skill is everything so they want to develop that skill by joining ESA.

In several meetings, the members of ESA made a deal to have spoken materials, for example studying debate, pronunciation and other spoken materials. When they had grammar material, they also did not study it in written form. They studied it using peer teaching. Every team, there was one student who become tutor. Then he/she explained orally and the others listened and wrote the points. Moreover, they asked and shared their knowledge each other by asking and answering (spoken). They were so 
motivated to learn and share the knowledge to their partner. For that reason, this condition showed that the environment and motivation affect the process of english language learning (Raja, B.W.D and Selvi, 2011, p. 40).

They do realize and understand that ESA has big role for their English skills development. Nevertheless, unluckily, many students are not aware with that program. They are reluctant to join it because of various reasons. Most of them who could not come had reasons because they had other programs that they must join in the same time. For example, they must work, join the Islamic Boarding School or pondok programs, and had other agenda in the same time. Those reasons are so logic if they were difficult to join ESA program. Some students wanted to join but they could not. On the other hand, there were so many students who had time but they were reluctant to join. So many reasons causes their absence. Many of them said that they were so lazy, not motivated to join because uninteresting material, inappropriate and not fun teaching strategy/learning and unclear organization structure/program/material.

If they are analyzed, there were some reasons why ESA has no unclear organization structure/program. The first is the organization structure just run for a semester, not for a year. The transition of Sekolah Tinggi Agama Islam Negeri (STAIN) Kudus to be Institut Agama Islam Negeri (IAIN) Kudus also becomes the reason or factor because the organization structure and regulation is different. It was like the explanation by the leader of Himpunan Mahasiswa Jurusan (HMJ). The unclear regulation in this transition period made ESA not clear to determine the next step. And the last reason was the selfstudents commitment, motivation and character. They often did not attend the program because they had ESA class after joining the lecturing program and that day was hot. That little thing should not be the problem to stop their attendance. 


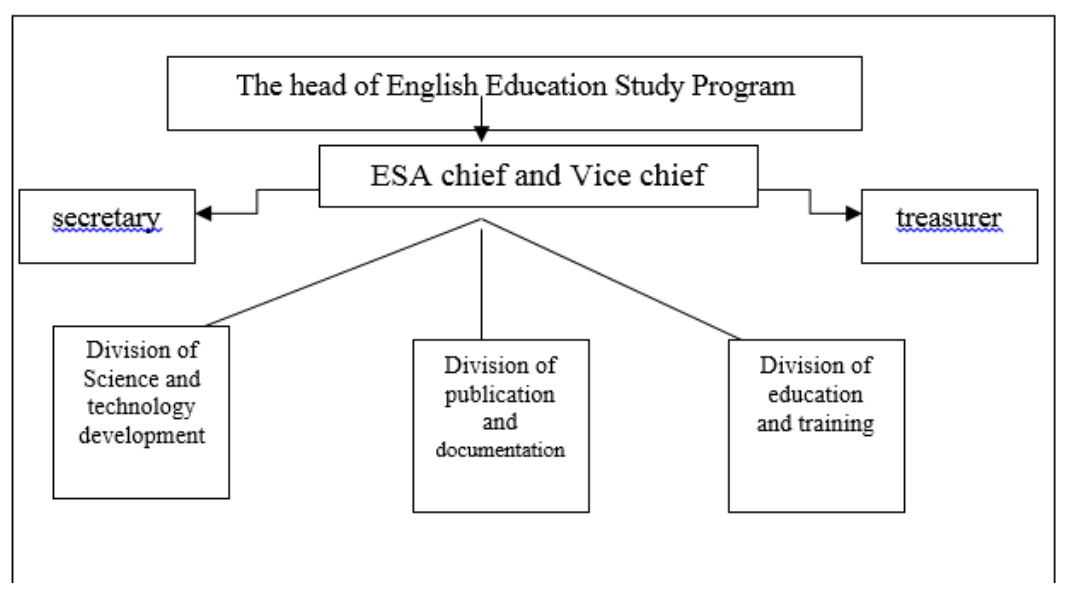

Figure 1. The Organization Structure of ESA STAIN Kudus

Factors influencing the English Education Department students at STAIN Kudus to develop their English Skills in English Students Association (ESA)

After analyzing the data, the researcher classified the factors influencing the English Education Department students at STAIN Kudus to develop their English Skills in English Students Association (ESA) into two categories. They are internal and external factors. The internal factors are students' self-motivation and character. Although they said that ESA is important for their English skills development, many of them did not join the program. They gave several reasons to avoid the program. On the other hand, the researcher found some students who have high motivation. Although they have good ability and skills in English, they realize that ESA is important and they must join it. Moreover, they have good intention. Whatever condition, they always asked the others to join ESA, tried to have positive thinking and they also realized that asking and motivating the others categorized as the first academic year students at EED IAIN is not easy, especially if they have low motivation. They come and ask the others to join because they do not look at the others left behind. It means that they want all students have good motivation and English skills. Their intention is responded well by some students. Nevertheless, some students gave not good or bad response. 
And the external factors are environment. For environment, there are some aspects. First is the condition and the availability of classroom. In IAIN Kudus, there are so many classes and buildings, but the number of the students are so massive. There, finding the empty room is so difficult, like finding needle in the bushes. At day of ESA, several times they must go around to find the empty class. They often proposed to have ESA outdoor class, but in the environment of IAIN Kudus is so hot. If they must have class outside campus, another problem came. For example, some of them did not have motorcycle because of staying in the boarding house or dormitory. The other friend are also the cause to a student to join ESA or not, especially close friend.

The next factor is syllabus/lesson plan and materials/programs. In the beginning of the even semester of 2017/2018, the materials were listed. They tried to make a handout together based on their needs. If there is no lecturer who guided them, they would study autonomously by peer teaching/learning. Nevertheless, they do not finish the handout yet. Hopefully, it can be completed next academic year, 2018/2019 so they can be facilitator to their juniors.

Most of them do hope the existence of native speakers. They always expect that the tutor is not just from the lecturer or their friends. They want the native speaker can guide them well so they can practice English directly with native speaker related to the pronunciation, intonation, culture, and many more. Well preparation is also needed so they will have interesting and fun class. Teaching technique/strategy which is monotonous made them bored so they need to have games to raise their motivation up. Because it is ESA class, different from lecturing class, they wanted to have fresh and fun learning.

Solutions for the problems of English Education Department students at STAIN Kudus in developing their English Skills in English Students Association (ESA). After knowing the problem faced in ESA IAIN Kudus. All parties must formulate the solution to solve the problems. Based on the interview done to the students and lecturers, the commitment of the students and lecturers to 
run the ESA program must be kept. Nevertheless, students should be able to be autonomous to run the program because the number of English lecturers is limited and all of them get more class to teach.

English Education Department must facilitate and pay big attention to this program. Starting a new program is not easy if it is not supported by the committed people. For avoiding the boredom, the students need to have outdoor class, for example visiting tourism object to hunt tourist so they can practice their English skill with the native speakers. Otherwise, the department can cooperate with certain institution or organization so there will be native speakers who teach in EED IAIN Kudus.

\section{Conclusion}

The students need the space to elaborate and develop their English Language skillss. An organization for them can be a great chance to facilitate their expectation. At IAIN Kudus, students finally have English Students Association (ESA) to study more about English outside of classroom, Based on the discussion, there are three conclusions. First, the role of English Students Association (ESA) in developing English skills of English Education Department students at STAIN Kudus is important and very big, especially for improving their speaking skills. Second, there are internal and external factors influencing the English Education Department students at STAIN Kudus to develop their English Skills in English Students Association (ESA). The internal factors are students' self-motivation and character and the external factors are environment (class or other friends' condition/influence), syllabus/lesson plan, materials/programs, teaching technique/strategy, level of regulation, and several agenda/programs in the same time. Third, solutions for the problems of the English Education Department students at STAIN Kudus in developing their English Skills in English Students Association (ESA) are the existence of clear organization structure and regulation, well-organized materials/class, 
interesting and fun programs, students and lecturers' support and appreciation.

\section{Acknowledgement}

This article is the research report of BOPTN 2018, STAIN Kudus. For that reason, the writer expresses her gratitude to Pusat Penelitian dan Pengabdian Kepada Masyarakat (P3M) STAIN Kudus and Religion Ministry Republic of Indonesia that gave the great chance to her to conduct the research.

\section{References}

Arikunto, S. (1998). Prosedur Penelitian: Suatu Pendekatan Praktek. Jakarta: Rineka Cipta.

Bungin. (2003). Analisis Data Penelitian Kuantitatif. J akarta: Rajawali Press.

Dewi, R.S, Kultsum, U. dan Armadi, A. (2017). Using Communicative Games in Improving Students' Speaking Skills. English Language Teaching J ournal: Canadian Center of Science and Education, 10(1).

Harmer, J. (2007). How To Teach English. Essex, England: Pearson Education Limited.

Hedge, T. (2008). Teaching and Learning in the Language Classroom. Oxford: Oxford University Press.

Khajloo, A. I. (2013). Problems in Teaching and Learning English for Students. International J ournal of Engineering Research and Development. 7(3).

Lamber, V.A and Lamber, C. . (2012). Qualitative Descriptive Research: An Acceptable Design. Pacific Rim International J ournal of Nursing Research.

Leask, B. and Carroll, J . (2013). A Quick Guide to Developing English Language Skills. IEAA.

Lincoln, YS. and Guba, E. (1985). Naturalistic Inquiry. Newbury Park, CA: Sage Publications.

Oradee, T. (2012). Developing Speaking Skills Using Three Communicative Activities (Discussion, Problem-Solving, and Role-Playing). International J ournal of Social Science and 
Humanity, 2(6), 533.

Raja, B.W.D and Selvi, K. (2011). Causes of Problems in Learning

English as a Second Language as Perceived by Higher Secondary students. ERICK: J ournal on English Language Teaching, 1(4).

Rodriguez, G. L. A. (2017). Students' Language Skills Development through Short Stories. IKALA J ournal, 22(2).

Sutopo, H. B. (2006). Metodologi Penelitian Kualitatif, Dasar Teori dan Terapannya in Pendidikan. Surakarta: Sebelas Maret University Press. 
This page intentionally left blank 